\title{
Lean Manufacturing: Context, Practice Bundles, and Performance
}

\author{
Rachna Shah \\ Carlson School of Management \\ University of Minnesota \\ Minneapolis, MN 55455 \\ E-mail: $\underline{\text { Shah.21@osu.edu }}$
}

Peter T. Ward*

Fisher College of Business

The Ohio State University

Columbus, OH 43221

(614) 292-5294

E-mail: Ward.1@osu.edu

*corresponding author

August 2002

Copyright $\subseteq 2002$ 


\title{
Lean Manufacturing: Context, Practice Bundles, and Performance
}

\begin{abstract}
:
Management literature has suggested that contextual factors may present strong inertial forces within organizations that inhibit implementations that appear technically rational (Nelson and Winter, 1982). This paper examines the effects of three contextual factors, plant size, plant age and unionization status, on the likelihood of implementing twenty-two manufacturing practices that are key facets of lean production systems. Further, we postulate four "bundles" of interrelated and internally consistent practices; these are Just-in-Time, Total Quality

Management, Total Preventive Maintenance, and Human Resource Management. We empirically validate our bundles and investigate their effects on operational performance. The study sample uses data from IndustryWeek's Census of Manufacturers. The evidence provides strong support for the influence of plant size on lean implementation, whereas the influence of unionization and plant age is less pervasive than conventional wisdom suggests. The results also indicate that lean bundles contribute substantially to the operating performance of plants, and explain about 23 percent of the variation in operational performance after accounting for the effects of industry and contextual factors.
\end{abstract}

Keywords: contextual factors, lean manufacturing practices, lean bundles, operational performance. 


\section{Lean Manufacturing: Context, Practice Bundles, and Performance}

\section{Introduction}

Heightened challenges from global competitors during the past two decades have prompted many US manufacturing firms to adopt new manufacturing approaches (Hall, 1987; Meredith and McTavish, 1992). Particularly salient among these is the concept of lean production (Womack and Jones, 1996, Womack, Jones, and Roos, 1990). Lean

production is a multi-dimensional approach that encompasses a wide variety of management practices, including just in time, quality systems, work teams, cellular manufacturing, supplier management, etc. in an integrated system. The core thrust of lean production is that these practices can work synergistically to create a streamlined, high quality system that produces finished products at the pace of customer demand with little or no waste. Anecdotal evidence suggests that several organizational factors may enable or inhibit the implementation of lean practices among manufacturing plants. With the notable exception of White et al., (1999), there is relatively little published empirical evidence about the implementation of lean practices and the factors that may influence implementation.

A majority of articles on the topic of lean production system focus on the relationship between implementation of lean and performance. While most of these studies have focused on a single aspect of lean and its performance implications (e.g. Hackman and Wageman, 1995; Samson and Terziovski, 1995; McKone et al., 2001), a few studies have explored the implementation and performance relationship with two aspects of lean (e.g. Flynn et al., 1995; McKone et al., 2001). Even fewer studies have 
investigated the simultaneous synergistic effects of multiple aspects of lean implementation and performance implication. A noteworthy exception is Cua et al.'s, (2001) investigation of implementation of practices related to Just-in-Time (JIT), Total Quality Management (TQM), and Total Preventive Maintenance (TPM) programs and their impact on operational performance. However, conceptual research continues to stress the importance of empirically examining the effect of multiple dimensions of lean production programs simultaneously.

We examine the relationship between contextual factors and extent of implementation of a number of manufacturing practices that are key facets of lean systems. These contextual factors have been suggested as possible impediments to implementing lean production systems. Specifically, we focus on three contextual factors, plant size, plant age, and extent of unionization. Further, we extend Osterman (1994) and MacDuffie’s (1995) notion of “bundles” from human resource practices to a larger set of manufacturing practices. Specifically, we postulate four "bundles” of interrelated and internally consistent practices; these are Just-in-Time (JIT), Total Quality Management (TQM), Total Preventive Maintenance (TPM), and Human Resource Management (HRM). We empirically validate our bundles and further investigate their simultaneous and synergistic effects on operational performance.

\section{Literature and Propositions}

\section{$2.1 \quad$ Lean practices and lean bundles}

In the last several years, scholarly journals have published a number of articles that focus on the content of lean production or comprise of case studies that concentrate 
on individual firm experiences. A review of this literature reveals a number of manufacturing practices that are commonly associated with lean production. Table 1 summarizes our review by cross listing key practices identified with references.

Table 1 about here

Table 1 links substantive literature on high performance, lean manufacturing with each of the lean practices addressed in our research. As can be seen, there is varying degree of frequency that each of the items selected is considered in the studies reviewed. JIT/Continuous flow production and quick changeover methods are included most frequently, while safety improvement methods are referenced least frequently in the literature. The practices shown in Table 1 emerge from a fairly extensive literature review and provide a representative view of the components comprising lean production. Our discussion and measurement of lean production is necessarily related to the manufacturing practices that are commonly observed in the literature describing high performance, lean manufacturers. This literature is also rich with descriptions of values and philosophy associated with lean production that are less readily measured than practices. For example, lean production philosophy focuses on avoiding seven cardinal wastes and on respecting customers, employees and suppliers (Schonberger, 1986). Although we do not directly address such philosophical positions, we recognize that they are important and believe that they are reflected in the implementation of the lean practices that we do address. 
There are multiple ways to combine the individual practices to represent the multi-dimensional nature of lean manufacturing. In combining these practices, the researcher has to contend with the method used to combine and the actual content of the combinations. The dominant method in operations management literature has been to use exploratory or confirmatory factor analysis to combine individual practices in a multiplicative function to form orthogonal and unidimensional factors (Flynn et al., 1995; Cua et al., 2001). A review of research from organization theory, and labor and human resource management shows less reliance on factor analysis and offers multiple ways for combining individual practices and creating an index. One such method is the additive index used by Osterman (1994) and MacDuffie (1995) in developing "bundles” of interrelated human-resource management practices. We used the additive index method for developing our lean bundles.

There is general agreement within operations management literature that Just In Time (JIT), Total Preventive Maintenance (TPM), Total Quality Management (TQM), and Human Resource Management (HRM) are conceptually, theoretically, and empirically well established (Ahire et al., 1996, Samson and Terziovski, 1999, Davy, 1992; Cua, 2000; Flynn et al., 1994; Flynn et al., 1995; McKone and Weiss, 1999; McKone et al., 1999; McLachlin, 1997; Sakakibara et al., 1997; Schroeder and Flynn, 2001, Osterman, 1994; Pil and MacDuffie, 1996; Ichniowski et al., 1994). We selected inter-related practices to combine into four practice bundles associated with JIT, TPM, TQM and HRM.

We use individual practices to investigate the association between contextual factors and the pattern of implementation because we are interested in the pattern of 
implementation among the twenty-two manufacturing practices. We use the four bundles in examining the relationship between implementation and operational performance because we are interested in evaluating the synergistic effects of implementation of all complementary facets of lean.

\subsection{Implementation and Contextual Variables}

In general, the success of implementation of any particular management practice frequently depends upon organizational characteristics, and not all organizations can or should implement the same set of practices (Galbraith, 1977). Consideration of organizational contexts has been noticeably lacking in research on implementation of JIT and TQM programs or other lean manufacturing practices. Perhaps because of the failure to consider organizational context, evidence on the impact of JIT and TQM programs on organizational performance has been mixed (Adam Jr., 1994; Powell, 1995; Samson and Terziovski, 1999).

In this study, we examine three organizational context characteristics unionization, plant age and plant size - that may influence the implementation of manufacturing practices. A limited number of empirical studies suggest that implementation or adoption of a manufacturing practice is contingent upon specific organizational characteristics (White et al., 1999; McKone et al., 1999). For example, White et al. (1999) found significant evidence that large US manufacturers adopted JIT practices more frequently than small manufacturers. While the role of plant size in implementation process has been studied previously, plant age and unionization status 
remains comparatively unexplored. There is not only a lack of empirical attention given to contextual factors' relationship with lean practices, but there is also a paucity of theory to guide our expectations about the direction of possible effects. Because of the exploratory nature of this research, we develop a set of propositions rather than formal hypotheses.

Unionization: It is often assumed that because implementation of most manufacturing practices requires negotiating changes in work organization, unionized facilities will resist adopting lean practices and thus lag behind non-unionized facilities. Drucker (1987) discussed the problems of existing union work rules and job classifications in the implementation of JIT systems. In a similar vein, the business press has often asserted that unionization prevents the adoption of some "Japanese" manufacturing practices in US manufacturers. Further, there are also instances in which unions have been cooperative and helpful in the implementation process (Katz, 1985; Cappelli and Sherer, 1989).

While there is some evidence that unionization is negatively associated with organizational performance (Machin, 1995; Meador and Walters, 1994; Bronars, Deere and Tracy, 1994), empirical evidence linking unionization with adoption and implementation of manufacturing practices is scant. For instance, Ahmed et al., (1991) found that in a sample of 177 manufacturing firms, union's attitude towards flexibility was not significantly related to JIT usage. In the investigation of influence of unions on human resource management practices, Ng and Maki (1994) concluded that the impact of union varies, depending upon the nature of the practice. In manufacturing firms, 
Osterman (1994) found no empirical support for association between unionization and four innovative work practices. Unionization seems to be an important factor for implementation although the direction is not exactly clear. In addition, it hasn't been empirically investigated in association with a wider set of lean manufacturing practices. Thus, the net effect is an empirical question, which we propose to test as follows:

Proposition 1: Unionized plants are less likely to implement lean manufacturing practices than non- unionized or partially unionized plants.

Age of the plant: Plant age may imply either a tendency toward resistance to change or a liability of newness. The "resistance to change" view is supported by the organizational sociology literature which suggests that the age of an establishment should inversely influence the rate of adoption of innovations, because organizational forms tend to be “frozen” at birth (Stinchcombe, 1965). Evolutionary economics provides additional support for this view (Aldrich, 1979; Nelson and Winter, 1982). The evolutionary perspective suggests that organizations develop a set of organizational routines (manufacturing practices) over a period of time and these practices change infrequently. Further, the longer an organization has experience with the practices, even if the results are inferior relative to the new practices, the harder it is for the organization to replace the older, inferior practices (Pil and MacDuffie, 1996). So, an older organization finds implementing new practice(s) more challenging. Organizational ecologists espouse the same view as "liability of newness." This perspective suggests that older organizations have an advantage over younger ones because it is easier to continue existing routines 
than to create or borrow new ones, even if the new routines are inherently superior.

(Nelson and Winter, 1982; Hannan and Freeman, 1984).

Thus irrespective of the theoretical perspective, plant age is found to impede adoption and implementation of new, innovative work practices. However, empirical evidence from industrial and labor relation literature indicates that age of an establishment is not a significant determinant of adoption of work practices. Specifically, Osterman (1994) using data from 694 US manufacturing establishments found that age was not associated with the adoption of innovative work practices such as teams, jobrotation, quality circles, and total quality management. Osterman (1994) study was limited to innovative work practices related to human resource management.

We study a wider set of manufacturing practices related not only to human resources but also workflow in production, preventive maintenance and quality management programs. In this regard, anecdotal evidence suggests that newer plants have a natural advantage in implementing new lean practices because of a younger, arguably less cynical workforce and also because of fewer physical barriers to lean practices such as set up time reduction. This implies that plant age has a negative impact on the likelihood of implementation of lean manufacturing practices. Thus, we propose the following with regards to age of the plant:

Proposition 2: Older plants are less likely to implement lean manufacturing practices than newer plants. 
Size of the Plant: Several authors (e.g. Chandler, 1962; Child, 1972) have noted that since any administrative task tends to be more complicated in large firms, managers may not even attempt to change, instead they may allow existing systems to linger. This is equally true of implementation of new operational practices. That is, large organizations suffer from structural inertial forces (Hannan and Freeman, 1984) that negatively effect the implementation of lean manufacturing practices. Further, inertial effects of size are more prevalent in manufacturing industry than in service industry (Gopalakrishnan and Damanpour, 1997). However, large size also implies the availability of both capital and human resources that facilitate adoption and implementation of lean practices as well as returns to scale for investments associated with lean practices. The influence of size is pervasive and has been identified in relation to technology practices (Germain et al., 1994) and manufacturing practices (White et al., 1999), across industries as diverse as hospitals (Moch, 1976), education (Baldrige and Burnham, 1975), as well as manufacturing (Ahmed et al., 1991). Thus, while theoretical arguments can be made both in support of a positive and a negative association between large size and implementation of lean practices, empirical evidence overwhelmingly supports a positive relationship. That is, despite the inertial effects, large firms are more likely to implement lean practices than their smaller counterparts. So, we propose the following with regard to firm size and implementation:

Proposition 3: Large manufacturers are more likely to implement lean practices than small manufacturers. 
Each of these issues has the same underlying theme - strong inertial forces within organizations that prevent even implementations that appear technically rational from manifesting themselves in practice (Nelson and Winter, 1982) balanced against a competitive imperative of continuous improvement. Thus, organizational context may significantly impact the implementation of lean manufacturing practices.

\subsection{Bundles of Lean manufacturing practices and Operational Performance.}

Lean practices are generally shown to be associated with high performance in a number of studies of world-class manufacturing (e.g., Sakakibara et al., 1997; Giffi et al., 1990). Overall, review of related research indicates that implementation of lean practices is frequently associated with improvements in operational performance measures. The most commonly cited benefits related to lean practices are improvement in labor productivity and quality, along with reduction in customer lead time, cycle time, and manufacturing costs (Schonberger, 1982; White et al., 1999).

Most of the empirical studies focusing on the impact of lean implementation on operational performance are constrained to one or two facets of lean, often JIT or TQM. Improved operational performance associated with JIT practices (Koufteros et al. 1998; Sakakibara et al., 1997; Im and Lee, 1989; White et al., 1999) has been shown to outweigh the results associated with TQM practices (Samson and Terziovski, 1999; Powell, 1995). In a study of JIT and TQM, Flynn et al., (1995) found incremental performance effects attributed to JIT and infra-structural practices common to both JIT and TQM, but not specific TQM practices. In case of TQM practices by themselves, while Choi and Eboch (1998), and Samson and Terziovski (1999) found a significant 
direct impact of TQM practices on operational performance, Adam Jr., (1994) and Powell (1995) found little impact of TQM practices on operational and other measures of performance. Powell (1995) found positive support for only 3 out of 12 TQM practices that he studied.

Despite variable evidence regarding performance improvements related to these lean practices, relatively little empirical research exists to gauge the extent of performance improvements. Further, an empirical investigation of simultaneous use of several manufacturing programs representing multiple facets of lean is also lacking in the literature. We seek to address this apparent gap in literature by examining the performance implications of implementing lean practices after controlling for the effects assigned to industry differences and the contextual factors.

Many researchers argue that a lean production system is an integrated manufacturing system requiring implementation of a diverse set of manufacturing practices (e.g. Womack and Jones, 1996). Further, they also suggest that concurrent application of these various practices should result in higher operational performance because the practices, although diverse, are complementary and inter-related to each other. For instance, reduction in work-in-process inventory goes hand in hand with development of human resource capability in the form of empowered/self-directed work teams capable of solving problems. Thus, the problem solving capabilities that arise as a result of empowered work teams can help boost performance by identifying root causes of quality problems, by helping to improve workflow, and by improving equipment efficiency. Thus, we posit that simultaneous application of multiple aspects of lean manufacturing will have a significant positive impact on operational performance: 
Proposition 4: Implementation of lean bundles, each representing groups of related lean practices, will have a positive impact on operational performance.

\section{Methods}

\subsection{Instrument Development and Data Collection}

Penton Media Inc., publishers of IndustryWeek and other manufacturing related publications, conduct an annual survey of manufacturing managers and made their 1999 data available to the authors. IndustryWeek (IW) is an industrial magazine targeted at executives and managers of U.S. manufacturing firms. Penton Media Inc. and PricewaterhouseCoopers jointly developed a mail survey with input from a number of manufacturing experts external to both firms. The survey included four pages of questions related to human resource management, quality issues, customer and supplier relations, and technology.

The study sample consists of approximately 28,000 subscribers to Penton Media Inc.'s manufacturing-related publications, and includes managers of plants belonging to manufacturing firms. Survey recipients hold titles such as plant manager, plant leader, and manufacturing manager. The unit of analysis in the present study is the manufacturing plant and the respondents characterize activities with suppliers and customers from that perspective. Each individual in the sample was sent a letter describing the survey, a survey form, a business reply envelope, and a separate participation card to ensure anonymity of responses. The questionnaires were mailed in mid-April 1999 and completed questionnaires were accepted through early June 1999. A 
total of 1757 completed surveys were received corresponding to a response rate of approximately 6.7 percent. While the response rate is smaller than many empirical studies, it compares favorably with large sample operations surveys (e.g. Roth and van der Velde, 1991, Stock et al., 2000). In light of the low response rate, non-response bias was assessed by comparing the proportion of respondent firms to proportion of total mailed surveys for each SIC code. The data indicate no significant difference $\left(\chi^{2}=12.3\right.$, $\mathrm{df}=19, \mathrm{p}=.83)$

3.1.1. Sample Characteristics: The sample resembles the population profile reported by US Census of Manufacturers (1997) and is not unlike those for similar studies of US manufacturers (e.g. Im and Lee, 1989; White et al., 1999). A comparison of the number of establishments in the IW sample with the population profile reported by US Census of Manufacturers (1997) is shown in Table 2. The comparison indicates that compared to the population as a whole, the IW sample is somewhat biased in favor of paper, chemicals, primary metal, electric and electronic equipment and transportation equipment. Despite the differences from the US population's industry composition, the sample provides diverse and fairly representative industrial coverage. Survey items appear in appendix A.

Table 2 about here

The manufacturers included in the sample represent a wide variety of industries. Although implementing lean practices is usually associated primarily with discrete part 
manufacturers, pervasiveness of practices across the industrial spectrum is unknown. For this reason, we include respondents from all manufacturing industries (SIC 20 to 39) in the sample. We report the analysis related to industry effects in our findings. A majority of plants included in the sample have a non-union production environment (65 percent), are more than 20 years old (72 percent), and are relatively small in size, having fewer than 250 employees (52 percent). The sixty-five percent of respondent plants that are not unionized corresponds to an estimated fifty-nine percent of all manufacturing plants that are not unionized as reported in the most recent economic census (US census of manufacturers, 1997). All of the manufacturers included in the sample have implemented at least one lean practice.

\subsubsection{Contextual Variables: Each of the contextual variables is recoded into three} categories. When a union represents none of the plant's production workforce, we classify it as "non-unionized” plant, instances of 100 percent unionization are classified as "unionized" plants, and plants within these two extremes are classified as "partly unionized” plants. Guidelines for classifying plants on the basis of age are scant. IndustryWeek suggests categorizing plants less than 10 years old as "new" plants and more than 20 years old as “old” plants. We use these criteria for our study. In addition, we classify plants between the age of 10 and 20 years as “adolescent” plants. Size is recoded into small, medium and large plants. We designate plants with fewer than 250 employees as "small” following Adams and Ponthieu, (1978, pp. 2) and plants with more than 1000 employees as “large” following White et al (1999) and the plants between 250999 as medium sized plants. 
3.1.3. Lean Manufacturing Practices: Lean manufacturing practices are measured on a three-point scale (1=no implementation; 2=some implementation; 3=extensive implementation). Scale length has been the focus of considerable discussion in the survey methods literature. While some research shows that reliability increases with scale length (Lissitz and Green, 1975; Jenkins and Taber, 1977), there is no clear-cut relationship between validity and scale length (Smith, 1994; Smith and Peterson, 1985). Specifically, Morrison (1972) shows that 3-point scales capture most real information about construct relationships and are thus considered adequate. A correlation matrix for each of the contextual variables and lean practice included in the analysis is shown in Table 3.

Table 3 about here

3.1.4. Lean Bundles: The 22 individual lean practices were combined into four lean bundles. For instance, all practices related to production flow were combined to form the JIT bundle. The underlying rationale is that JIT is a manufacturing program with the primary goal of continuously reducing, and ultimately eliminating all forms of waste (Sugimori et al., 1977). Two major forms of waste are Work-In-Process (WIP) inventory and unnecessary delays in flow time. Both can be reduced by implementing practices related to production flow such as lot size reduction, cycle time reduction, quick changeover techniques to reduce WIP inventory and by implementing cellular layout, 
reengineering production processes, and bottleneck removal to reduce unnecessary delays in the production process.

Practices related to continuous improvement and sustainability of quality products and process were combined to form the TQM bundle. It includes practices such as quality management programs, formal continuous improvement programs and process capability measurement capability.

The TPM bundle includes practices primarily designed to maximize equipment effectiveness through planned predictive and preventive maintenance of the equipment and using maintenance optimization techniques. More generally, emphasis on maintenance may also be reflected by the emphasis given to new process equipment or technology acquisition (Cua et al., 2001).

The HRM bundle has significant theoretical and empirical support. The most commonly cited practices are job rotation, job design, job enlargement, formal training programs, cross training programs, work teams, problems solving groups, and employee involvement (Ichniowski et al., 1994; MacDuffie, 1995; Osterman, 1996). We include two practices in the HRM bundle - flexible, cross-functional work force, and selfdirected work teams. Flexible, cross-functional work force, and self-directed work teams are higher-level practices that include many lower level practices. Conceptually, in order for an organization to have a flexible cross-functional work force, it needs to have a jobrotation program, it needs to consider job design, and formal, cross functional training programs have to be in place. Similarly, self-directed work teams require that employees are organized in work teams and involved in problem solving groups. Boyer and Pagell (2000) have suggested eliminating lower level variables when these are included in 
higher-level constructs. Thus, we combine these two practices into HRM bundle to represent a much wider set of underlying HRM practices.

Each of the bundles was formed by adding the scores for each of the practices included in the bundle for each responding plant. The bundles were empirically validated using reliability analysis (Cronbach Coefficient Alpha) and principal components analysis with varimax rotation. All 22 lean practices were entered for principal component analysis (PCA). Varimax rotation was used to extract orthogonal factors (see Table 4) and four factors were extracted. The factors conform almost perfectly to the conceptual bundles with the sole exception of "competitive benchmarking." Competitive benchmarking is conceptually linked to TQM practices and we had included it in the TQM bundle. The rotated component matrix results indicate that it has a higher loading on the TPM (.364) factor compared to TQM (.361). However, because the difference in the loadings is not statistically significant we opted to include it in the TQM factor.

Table 4 about here

The results were replicated using oblique rotation as a check for orthogonality and the extracted factors were identical. Further, we checked the unidimensionality of each of the factors by conducting PCA at the factor level. More specifically, we entered only the items that load on one factor to ensure that they do indeed load on one factor. All four factors are unidimensional. Cronbach’s coefficient alpha is above the acceptable limit except for Human Resource Management Bundle., which is a two item factor. The 
value of Cronbach alpha depends upon the number of items in the scale and the average inter-item correlation (Carmines and Zeller, 1979, pp.45). Thus, keeping the average inter-item correlation constant, as the number of items increase, the value of alpha also increases. In this instance, if the number of items in the HRM practice bundle were increased from 2 to 4 while keeping the average inter-item correlation constant at .51, the Cronbach alpha value will increase to above .79 .

3.1.5. Operational Performance: A six-item scale is used to measure the operational performance of a manufacturing plant. The items include 5-year changes in manufacturing cycle time, scrap and rework costs, labor productivity, unit manufacturing costs, first pass yield, and customer lead time. A scale was constructed for operational performance measure based on principal components analysis of these items and the factor scores were used as the dependent variable. As shown in Table 5, all six items load on one factor, with an eigenvalue of 2.37 explaining almost 40 percent of the variation. Cronbach's coefficient alpha is 0.69 .

Table 5 about here

The construct validity issue of whether operational performance is unidimensional in a conceptual sense is a separate question from the empirical issue. Two competing and equally valid conceptual views on performance are the tradeoff view and the production competence view popularized by Skinner (1978) and Vickery (1991) respectively. We argue that firms are capable of developing multiple internal competences. Further, global 
competition requires that firms develop and possess these multiple competences in order to succeed. Our measure focuses on three underlying aspects that are highly related: lead-time, cost, and conformance quality. The very basis of JIT is that manufacturing processes that are faster and more precise with regard to first-time-through quality are also inherently less costly. Thus, we contend that these six measures are conceptually and empirically related and represent a single dimension of operational performance.

\section{Results}

\subsection{Context and Implementation of Lean Practices}

We use likelihood ratio chi-square test statistic to evaluate the relationship of association between contextual factors and implementation of lean practices. For example, for plant size and cellular manufacturing, the 3X3 (small/medium/large size X no/some/extensive implementation) matrix is decomposed into 3 separate $2 \mathrm{X} 2$ component matrices. The likelihood ratios are then compared to evaluate the direction of the overall association. We first computed a likelihood ratio chi-square statistic for each of the 22 lean manufacturing practices and each individual contextual factor. The results are discussed below for each of the contextual factors.

\subsubsection{Union Representation.}

Of the 22 lean manufacturing practices, six are significantly associated with unionization. These practices are cellular manufacturing, cross functional work force, cycle time reduction, maintenance optimization, process capability measurements, and self directed work teams. The evaluation of $2 \mathrm{X} 2$ matrices for each of the six practices 
indicates that unionization is negatively related to implementation. This suggests that unionized plants are less likely to implement these six practices. It is interesting to note that both practices related to managing work force (i.e. cross functional work force and self directed work teams) are negatively related to unionization. No statistically significant relationship was found for the other 16 practices. Contrary to popular belief, the results show that unionization status does not have a significant impact on extensive implementation of most lean practices. This result is somewhat surprising in light of conventional wisdom about the difficulty of implementing improvement programs in a unionized environment. However, the findings do lend support to observations about the difficulty of changing work force rules in a union environment.

Table 6 about here

\subsubsection{Age of Plant}

The likelihood ratio chi-square indicates that eight out of the 22 lean practices are significantly influenced by age of the plant. Five of the eight have a significant negative association between age of plant and implementation of the practice, implying that old plants are less likely to implement these practices than newer plants. These five practices include cross-functional work force, cycle time reduction, JIT / continuous flow production, maintenance optimization, reengineered production process and self-directed work teams. Three lean practices, planning and scheduling strategies, safety improvement programs, and total quality management programs have significant positive association with age of plant. This implies that old plants are more likely to implement 
these practices relative to new plants. The results are consistent with the debate in the literature about "liability of newness" and "liability of obsolescence” (Hannan and Freeman, 1984; Baum, 1989). No significant relationship was found between plant age and implementation in 14 other instances. These results indicate that although plant age has some impact on the implementation of lean practices, the direction of the effect is not always as predicted.

\subsubsection{Size of the Plant}

Of the 22 lean practices examined, plant size significantly impacts all but two practices. No significant relationship was found between size and implementation of two practices: cross-functional work force, quality management programs. As predicted all the effected practices have a significant positive association between plant size and implementation. This suggests that large plants are likely to implement the twenty practices more extensively compared to small plants. The findings with respect to size are generally consistent with the findings of White et al (1999).

\subsubsection{Evaluation of Propositions 1-3}

Likelihood ratio chi-square statistic and the individual 2X2 matrix analyses provide unambiguous support for proposition 3 that large size has a significant impact in the implementation of 20 out of 22 lean practices. However, the evidence is not as apparent for proposition 1 (implementation is negatively related to unionization status) and for proposition 2 (implementation is negatively related to age of the plant). Unionized plants are less likely to implement only six of the twenty-two practices 
compared to non-unionized plants. Otherwise, unionization has no significant effect on likelihood of implementing any other lean practices. Similarly, proposition 2 suggests that plant age is negatively associated with implementation. We find mixed support for it. Our analyses indicate that five of twenty-two lean practices are less likely to be implemented in older plants. However, three additional practices are found to be significant but not in the predicted direction.

To show that our findings do not result merely from chance, we calculate the probability of obtaining our specific results. For instance, large size has a significant impact on implementation 20 out of 22 times. Thus, we wish to calculate the probability of twenty significant results by calculating the probability of 20 Type I errors, assuming there is no size effect. A general Ho can be stated as:

\section{Ho: $\quad$ Organizational context has no impact on implementation status of a lean} practice.

We use a binomial probability distribution and calculate $\mathrm{p}(\mathrm{x})$, the probability of " $x$ ” (number of) Type I errors for each of the contextual variables. The probability of getting 20 significant results by chance [p(20) Type I errors] is almost zero. Thus, we can say with nearly complete confidence that large size makes a significant impact on implementation status of lean practices. Similarly, six lean practices were more likely to be implemented by non-unionized facilities. The probability of getting six significant results by chance $[\mathrm{p}(6)$ Type I errors] is almost 0.00008 . Impact of plant age can be evaluated by examining the results of a trinomial distribution. Because five lean 
practices are more likely to be implemented by newer plants, we look at the probability of obtaining these results by chance. The probability of getting five significant results by chance [p(5) Type I errors] is almost 0.00003 while the probability of obtaining three significant results is 0.006 , indicating that one can be slightly more than 99 percent certain that plant age influences implementation of lean practices.

\subsection{Context, Lean Bundles, and Performance}

A hierarchical regression model is used to test the incremental effect of the lean practices on operational performance (Cohen and Cohen, 1975; Boyer et al., 1997). We use this technique to assess the incremental effects of lean bundles by controlling for the effects of industry, production process type, and organizational context. Operational performance is the dependent variable in each of the regression models.

First, 19 dummies for 2 digit SIC codes are entered as the regressor into the regression model to represent 20 industries present in the dataset. Various authors have noted the effect of industry on performance (Mauri and Michaels, 1998; McGahan and Porter, 1997; Dess, Ireland and Hitt, 1990). Therefore, this allows us to evaluate the incremental effect of organizational context and lean manufacturing practice independent of industry effects. Second, plant size, plant age, and unionization are entered into the regression model as regressors. This model establishes a baseline to serve as an effective control for the effects of context on performance. Finally, the factor scores for the four bundles are entered into the regression equation to establish their direct and incremental effect on operational performance after industry and context has been considered. We 
conducted the hierarchical regression analysis using the additive scores for the bundles as well, with almost identical results.

\subsection{1}

\subsubsection{Hierarchical Regression with Operational Performance as the Dependent}

Variable.

Table 7 shows the results of a hierarchical regression with operational performance as the dependent variable and industry effects, contextual variables, and lean practices entered in the sequential manner described above. Industry effects account for a small but significant amount of variance (adjusted $\mathrm{R}^{2}=0.024, \mathrm{p}<0.001$ ). This result is in conformance with McGahan and Porter (1997), who also found that the industry effects accounted for a relatively smaller portion of profit variance in manufacturing. Contextual variables as a group also account for a significant but small amount of variance (incremental $R^{2}=0.006, p<0.051$ ), and plant age is found to have a significant negative impact on operational performance.

The inclusion of bundles representing lean practices (model 3) results in a change in $\mathrm{R}^{2}$ of 0.231 , which is significant $(\mathrm{p}<0.000$ ). Overall, the model explains 27.7 percent of the variance in operational performance, with an associated significance at $\mathrm{p}<0.000$ as indicated by the p-value of the F test statistic. We also ran a fourth model, not shown, that included all 2- way interactions between all pairs of contextual variables and lean bundles. These interaction terms were not significant.

Table 7 about here 


\subsubsection{Evaluation of Proposition 4}

The analysis suggests that proposition 4 , that lean bundles are associated with higher performance, is supported. Each of the four bundles is positively associated with operational performance. As a group, they explain about 23 percent of the variation in operational performance even after accounting for the effects of industry and organizational context. The signs of all significant coefficients are positive, as expected. This provides support for the synergistic effects of implementing practices representing multiple aspects of lean manufacturing.

We also find no effect from unionization on performance after accounting for the effects of industry. This means that being unionized is unrelated to achieving superior values on the cost, time and quality measures that constitute operational performance. Plant age, on the other hand is negatively associated with operational performance, so that older plants do appear to be at a performance disadvantage.

We find that in model 3 (all variables included), plant size is negatively associated with operational performance. The size coefficient was not significant in model 2 (lean bundles not included). There is no evidence that size is collinear with other regressors. This finding indicates that large size does not translate into an advantage in operational performance and when the effects of lean bundles are considered, large size is actually a disadvantage with respect to operational performance.

Tolerance values, which are used to indicate the degree of multicollinearity, can range from zero to one with values near one indicating the presence of a high degree of collinearity. The tolerance values of the contextual factors with lean bundles in the 
model range from 0.833 to 0.907 indicating that some degree of multicollinearity affects these variables. To assess if multicollinearity between variables could cause potential problems in attributing performance effects to individual regressors, we calculated Variance Inflation Factors (VIF) for all coefficients (26 in all) in the regression equation for Model 3 to determine the existence of multicollinearity. Some experts in the field suggest that values below five indicate that multicollinearity problems do not affect the coefficient (Freund and Littell, 1986; Neter, Wasserman, \& Kutner, 1990). VIF for four coefficients, Dummy34, Dummy35, Dummy36, and Dummy37 (fabricated metal, machinery, electronics, and transportation equipment) exceeded the value of five, and VIF for all other coefficients was found to be below five. Thus, the overall regression model allows us to attribute performance effects to individual variables except for the four industry dummies noted above.

\subsection{The effect of industry}

The popular roots of lean manufacturing lie in the Toyota Production System and its many imitators in discrete part manufacturers around the world. However, lean practices clearly exist in every industry at least, in isolated pockets (Womack and Jones, 1996). The question of the extent of implementation of lean practices across industries has not been explored empirically. The question is salient in this research because it would not be productive to investigate industries where lean practices are not implemented or are only implemented to a limited extent.

We address the issue of extent of implementation of lean practices across industries by selecting two sets of industries, one that is representative of discrete 
manufacturing and the other that is largely process manufacturing. We then compare mean values of each of the four lean bundles for the two industry groups. Results of the comparison are reported in Table 8.

Table 8 about here

Significant differences between process and discrete industries are found in two of the four bundles. As might be expected, plants in discrete industries are more likely to implement JIT than those in the process industries where kanbans and small production lots are hard to imagine. Interestingly, TPM practices are more likely to be implemented by plants in process industries than in discrete industries. The mean values of TPM bundle between discrete and process industry are almost a perfect mirror image of mean values of JIT bundle. This finding makes sense when one considers the high degree of importance placed on capacity utilization in process industries (Hayes and Wheelwright, 1984). The remaining two bundles, TQM and HRM, present no significant differences between discrete and process industries.

Our conclusion is that bundles of lean practices are implemented across the industrial landscape. JIT practices are implemented more commonly in discrete industries but are fairly commonly implemented in process industries as well. The opposite relationship exists between TPM and industry type. TQM and HRM are implemented to about the same extent across both discrete and process manufacturing. These findings suggest that lean practices are prevalent in all industries and that studies 
of lean manufacturing need not be restricted to industries associated with discrete part manufacturing.

\section{Conclusion}

This research suggests two major findings. First, organizational context, i.e., plant size, unionization and plant age, matters with regard to implementation of lean practices, although not all aspects matter to the same extent. Second, applying synergistic bundles of lean practices concurrently appears to make a substantial contribution to operational performance over and above the small but significant effects of context. We discuss each of these findings in turn.

\subsection{The Importance of Context}

Each of the contextual variables under study is associated with a significant lore about their impact on the ability of manufacturers to implement various lean manufacturing practices. The conventional wisdom associated with unionization is that it is encumbering; that progress toward lean production is very difficult in the presence of unionized work force. Our findings do not bear out this contention. In fact, for 16 out of 22 lean practices there was no significant difference in the likelihood of implementation between union and non-union plants. However, the six practices that unionized plants are less likely to implement include "cross-functional workforce," a particularly thorny issue for plants with inflexible work rules imposed by collective bargaining agreements. Although the findings that we report suggest that having a unionized workforce is 
generally not a good reason for neglecting lean practices, certain practices are observed less frequently in a union environment.

Similar to the case of unionization, the expectation is that older plants, often employing older workforces, are more resistant to the changes required to implement lean practices. Again, the findings do not fully substantiate this contention. Our findings suggest that older plants are less likely to implement only five practices relative to newer plants. Included in this list are such important elements of a lean production system as cross-functional work force, cycle time reduction, JIT / continuous flow production, maintenance optimization, reengineered production process and self-directed work teams. However, likelihood of implementation of 14 of the lean practices is unaffected by plant age, and older plants are actually more likely to implement three practices relative to newer plants. Thus, the evidence is mixed. The data indicate that plant age is a more important inhibitor to implementing lean practices than is unionization, but the findings do not provide much cover for managers of older plants seeking a reason why lean practices cannot work in their plant. In fact, for many lean practices plant age is just not a significant factor.

More evidence exists supporting the idea that large plants are more likely to possess the resources to implement lean practices than smaller plants. These findings are consistent with the literature (e.g., White et al., 1999). Larger plants are more likely than smaller plants to extensively implement all but five of the lean practices under study. Interestingly, no differences in implementation likelihood were found for either crossfunctional workforce or quality management programs. An explanation may be that both 
of these practices are extremely important to achieving economies in smaller, high mix, plants and therefore these practices receive high level of attention in smaller plants.

We also find that implementation of lean bundles is ubiquitous across industries with reasonable high level of implementation of each of the lean bundles occurring in both process and discrete part industries. Although plants in discrete parts industries are somewhat more likely to implement JIT and plants in process industries are somewhat more likely to implement TPM, both types of plants implement both practice bundles. TQM and HRM bundles were about as likely in process or discrete parts plants.

Overall, the evidence presented here suggests that the organizational context significantly affects the likelihood of implementing lean practices. In particular, the influence of plant size appears to be substantial across a wide mix of practices. The influence of unionization and plant age, however, appear to be less pervasive than conventional wisdom suggests.

\subsection{Lean bundles and operational performance.}

The results suggest that implementation of each of the bundles of lean practices under study contribute substantially to the operating performance of plants. Proponents of lean production frequently point out that lean practices should be considered together as a system and that benefits accrue from all of the practices (e.g., Womack and Jones, 1996). Taking this point of view, consider the impact of all four bundles under study. These bundles explain about 23 percent of the variation in operational performance after controlling for the effects of industry and accounting for the effects of plant size, plant age, and unionization. It is also notable that both size and age exert a negative influence 
on performance when lean bundles are considered. Unionization, on the other hand, has no such negative influence.

Each of the individual lean practice bundles also contributes to performance $(\mathrm{p}<$ .0001). This means that a separate and identifiable incremental effect can be attributed to the four major lean practices areas that we have termed lean bundles.

A contribution of this research is that we identify four specific practice bundles from the literature, we validate the bundles empirically by extracting orthogonal factors consistent with the literature and we show that all four bundles are significantly related to performance.

Although the finding that each of the bundles contributes to performance may seem intuitive, such a result has not been reported previously in the literature. In fact, Flynn et al. (1995) report that JIT and common infrastructural practices have a positive effect on performance but that TQM has no significant effect. On the other hand, McKone et al., (2001) find that JIT, TQM and TPM all contribute to their weighted performance index.

These findings provide unambiguous evidence that the synergistic effects of all lean practices are associated with better manufacturing performance. The implication for managers of plants that are not implementing lean practices is also fairly clear. To not implement lean bundles is likely to put plants at a performance disadvantage compared to plants that do implement, regardless of size, age or level of unionization of the plant in question.

\subsection{Limitations and Future Research}


This research is carried out using secondary data made available by Penton Publishing. Although the data present a great opportunity, they also present some limitations. In particular, the low response rate allows the representativeness of the sample to be called into question despite the large sample size. There are also issues with self-reported performance data and possible single respondent bias. Despite these limitations, the data provide a rich picture of the manufacturing practices across many companies.

Based on the findings reported above, future research related to lean manufacturing clearly should control for the effects of size and industry. The positive findings with respect to the impact of context on the implementation of lean practices suggest that other environmental measures should also be considered in future research. Specifically, the effects of environmental dynamism, complexity and munificence might be considered in future research on lean manufacturing in context. Separate industry level analysis will also provide interesting insights, although lean practices are found in plants in all industries.

\section{Acknowledgements}

The authors would like to thank three anonymous reviewers for thoughtful, constructive suggestions that greatly improved this paper. We also thank the Center for Excellence in Manufacturing Management (CEMM) and Fisher College of Business, both at Ohio State University, for financial support. We are grateful to Penton Media, publishers of IndustryWeek, for allowing access to their data. 


\section{Appendix A: Survey items}

Contextual variables:

How many employees are at this location?

(Less than $100 ; 100-250 ; 250-499 ; 500-999 ; 1,000$ or more)

How many years has it been since plant start-up?

(Less than 5 years; 5-10 years; 11-20 years; More than 20 years)

Approximately what percent of plant production workers is represented by a union (s)?

(None; 1-25\%; 26-50\%; 51-75\%; 76-99\%; 100\%)

Operational Performance:

How has the following changed over the past five years?

Finished-product first-pass quality yield (reverse coded):

(Improved more than 40\%; Improved 21-40\%; Improved 1-20\%; Stayed the same; Declined 1-20\%; Declined more than 20\%)

Scrap and rework costs:

(Increased more than 20\%; Increased 1-20\%; Stayed the same; Decreased 1-20\%; Decreased 21-40\%; Decreased more than 40\%)

Productivity, defined as dollar volume of shipments per employee (reverse coded):

(Increased more than 80\%; Increased 41-80\%; Increased 21-40\%; Increased 11-20\%; Increased 1-20\%; Stayed the same; Decreased 1-10\%; Decreased more than 10\%)

Per unit manufacturing costs, excluding purchased material:

(Increased more than 20\%; Increased 11-20\%; Increased 1-10\%; Stayed the same; Decreased 1-20\%; Decreased more than 20\%)

Manufacturing cycle time:

(No reduction; Decreased 1-10\%; Decreased 11-20\%; Decreased 21-50\%; Decreased 51$75 \%$; Decreased more than $75 \%$ )

Customer lead-time:

(Increased more than 20\%; Increased 1-20\%; Stayed the same; Decreased 1-20\%; Decreased 21-40\%; Decreased more than 40\%) 


\section{References}

Adam Jr., E. E., 1994. Alternative quality improvement practices and organization performance. Journal of Operations Management, 12(1), 331-347.

Adams, S., Ponthieu, L. D., 1978. Administrative Policy and Strategy: A casebook. $2^{\text {nd }}$ ed. Grid Inc., Columbus, $\mathrm{OH}$.

Ahire, S. L., Goldhar, D. Y., Waller, M.A., 1996. Development and validation of TQM implementation constructs. Decision Sciences, 27 (1), 23-56.

Ahmed, N U., Tunc, E. A., Montagno, R. V., 1991. A comparative study of US manufacturing firms at various stages of just-in-time implementation. International Journal of Production Research, 29 (4), 787-802.

Aldrich, H. 1979. Organizations and environments. Englewood Cliffs, NJ: Prentice Hall.

Baldrige, V. A., Burnham, R. A., 1975. Organization Innovation: Individual, Organizational, and Environmental Impacts. Administrative Science Quarterly, 20(2), 165-176.

Baum, J. A. C., 1989. Liabilities of newness, adolescence, and obsolescence: The dissolution of organizational relationships and organizations. Proceedings of the Administrative Science Association of Canada, 10 (5), 1 -10.

Bicheno, J. R., 1989. Cause and effect of JIT: a pocket guide. Buckingham, U.K: PICSIE Books.

Boyer, K.K., Leong, G.K., Ward, P., Krajewski, L., 1997. Unlocking the Potential of Advanced Manufacturing Technologies. Journal of Operations Management, 15 (1), 331347.

Boyer, K.K., Pagell, M., 2000. Measurement issues in empirical research: Improving measures of operations strategy and advanced manufacturing strategy. Journal of Operations Management, 18 (3), 361-374

Bronars, S. G., Deere, D. R., Tracy, J. S., 1994. The effects of unions on firm behavior: An empirical analysis using firm-level data. Industrial Relations, 33 (4), 426-451.

Cappelli, P., Scherer, P. D., 1989. Spanning the union/nonunion boundary. Industrial Relations, 28 (2), 188-205.

Carmines, E.C., Zeller, R.A. 1979. Reliability and Validity Assessment. Beverly Hills, CA: Sage Publications. 
Chan, J. S., Samson, D. A., Sohal, A. S., 1990. An integrative model of Japanese manufacturing techniques. International Journal of Operations and Production Management, 10 (9), 37-56.

Chandler Jr., A. D., 1962. Strategy and structure: chapters in the history of the industrial enterpise. M.I.T. Press, Cambridge, MA.

Child, J., 1972. Organization structure and strategies of control - A replication of the Aston Study. Administrative Science Quarterly, 17 (2), 163-177.

Choi, T., Eboch, K., 1998. The TQM Paradox: Relations among TQM practices, plant performance, and customer satisfaction. Journal of Operations Management, 17 (1), 5975.

Cohen J., Cohen P., 1975. Applied Multiple Regression/Correlation Analysis for the Behavioral Sciences. Wiley and Sons, Hillsdale, NJ.

Cua, K. O., McKone, K. E., Schroeder, R. G., 2001. Relationships between implementation of TQM, JIT, and TPM and manufacturing performance. Journal of | Operations Management, 19 (2), 675-694.

Davy, J. A., White, R. E., Merritt, N. J., Gritzmacher, K., 1992. A derivation of the underlying constructs of Just-In-Time management systems. Academy of Management Journal, 35 (3), 653-670.

Dess, G. G., Ireland, R. D., Hitt, M. A., 1990. Industry effects and strategic management research. Journal of management, 16(1), 7-27.

Drucker, P. F., 1987. Workers hands bound by tradition. Wall Street Journal, Aug. 2, pp. 18.

Finch, B. J., Cox, J. F., 1986. An examination of just-in-time management for the small manufacturer with an illustration. International Journal of Production Research, 24 (2), 329-342.

Flynn, B. B., Sakakibara, S., Schroeder, R. G., 1995. Relationship between JIT and TQM: Practices and performance. Academy of Management Journal, 38 (5), 1325-1360.

Flynn, B. B., Schroeder, R.G., Flynn, E. J., 1999. World Class Manufacturing: an investigation of Hayes and Wheelwright's Foundation. Journal of Operations Management, 17 (2), 249-269.

Flynn, B. B., Schroeder, R. G., Sakakibara, S., 1994. A framework for quality management research and an associated measurement instrument. Journal of Operations Management, 11 (4), 339-366. 
Freund, R. J., \& Littell, R. C. (1986). SAS System for Regression. Cary, NC: SAS Institute Inc.

Galbraith, J. R., 1977. Organization Design. Addison Wesley Publishing Company, Phillipines.

Germain, R., Droge, C., Daugherty, P. J., 1994. A cost and impact typology of logistics technology and the effects of its adoption on organizational practice. Journal of Business Logistics, 15 (2), 227-248.

Giffi, C., Roth, A. V., Seal, G. M., 1990. Competing in world-class manufacturing: America's $21^{\text {st }}$ century challenge. Business One Irwin, Homewood, IL.

Gopalakrishnan, S.,_Damanpour, F.,_1997. A review of Innovation Research in

Economics, sociology, and technology management. Omega, 25 (1), 15-28.

Hackman, J. R., Wageman, R., 1995. Total Quality Management: empirical, conceptual, and practical issues. Administrative Science Quarterly, 40 (2), 309-342.

Hall, R. W., 1987. Attaining manufacturing excellence: just-in-time, total quality, total people involvement. Dow Jones-Irwin, Homewood, IL.

Hannan, M. T., Freeman, J., 1984. "Structural inertia and organizational change." American Sociological Review, 49 (2), 149-164.

Hay, E. J. 1988. The just-in-time breakthrough: Implementing the new manufacturing basics. John Wiley, New York.

Hayes, R. H., Wheelwright, S. C., 1984. Restoring our competitive edge: Competing through manufacturing. John Wiley, New York.

Im, J. H., Lee, S. M, 1989. Implementation of JIT systems in US manufacturing firms. International Journal of Operations and Production Management, 9(1), 5-14.

Ichniowski, C., Shaw, K., Prennushi, G., 1994. The effect of Human Resource Management on productivity. Working paper, Columbia University.

Jenkins, G.D., Taber, T. D., 1977. A Monte-Carlo study of factors affecting three indices of composite scale reliability. Journal of Applied Psychology, 62 (4), 292-298.

Katz, H., 1985. Shifting Gears: Changing labor relations in the U. S. Auto Industry. MIT Press, Cambridge, Mass.

Koufteros, X. A., Vonderembse, M. A., Doll, W. J., 1998. Developing measures of time based manufacturing. Journal of Operations Management, 16(1), 21-41. 
Lee, S. M., Ebrahimpour, M., 1984. Just-in-time production system: Some requirements for implementation. International Journal of Operations and Production Management, 4 (4), 3-15.

Lissitz, R.W., Green, S. B., 1975. Effect of the number of scale points on reliability: A Monte Carlo approach. Journal of Applied Psychology, 60 (1), 10-13.

MacDuffie, J. P., 1995. Human resource bundles and manufacturing performance: Organizational logic and flexible production systems in the world auto industry. Industrial and Labor Relations Review, 48 (2), 197-221.

Machin, S., 1995. Plant Closures and unionization in British Establishments. British Journal of Industrial Relations, 33 (1), 55-68.

Mauri, A. J., Michaels, M. P., 1998. Firm and industry effects within strategic management: An empirical examination. Strategic Management Journal, 19 (2), 211219.

McGahan, A. M., Porter, M. E., 1997. How much does industry matter, really? Strategic Management Journal, 18 (6-7), 15-30.

McKone, K. E., Schroeder, R. G., Cua, K. O., 2001. The impact of Total Productive Maintenance on manufacturing performance. Journal of Operations Management, 19 (1), 39-58.

McKone, K.E., Schroeder, R. G., Cua, K. O., 1999. Total productive maintenance: A contextual view. Journal of Operations Management, 17 (2), 123-144.

McKone, K.E., Weiss, E. N., 1999. Total Productive Maintenance: Bridging the gap between practice and research. Production and Operations Management, 7 (4), 335-351.

McLachlin, R., 1997. Management initiatives and just-in-time manufacturing. Journal of Operations Management, 15 (4), 271-292.

Meador, M. W., Walters J. K., 1994. Unions and Productivity: Evidence from academe. Journal of Labor Research, 15 (4), 373-386.

Meredith, J. R., McTavish, R., 1992. Organized manufacturing for superior market performance. Long Range Planning, 25 (6), 63-71.

Moch, M. K., 1976. Structure and Organizational Resource Allocation. Administrative Science Quarterly, 21 (4), 661-674.

Monden, Y., 1981. What makes the Toyota production system really tick? Industrial Engineering, 13 (1), 13-16. 
Morrison, D.G., 1972. Regression with discrete dependent variables: The effect on $\mathrm{R}^{2}$. Journal of Marketing Research, 9 (3), 338-340.

Nelson R. R., Winter, S. G., 1982. An evolutionary theory of economic change. Harvard University Press, Cambridge, MA.

Neter, J., Wasserman, W., Kutner, M. H., 1990. Applied Linear Statistical Models, 3rd ed. Irwin, Homewood, IL.

Ng, I., Maki, D., 1994. Trade union influence on human resource management practices. Industrial Relations, 33 (1), 121-135.

Osterman, P., 1994. How common is workplace transformation and who adopts it? Industrial and Labor Relations Review, 47 (2), 173-188.

Pegels, C. C., 1984. The Toyota production system: Lessons for American management. International Journal of Operations and Production Management, 4(1), 3-11.

Pil, F. K., MacDuffie, J. P., 1996. The adoption of high-involvement work practices. Industrial Relations, 35 (3), 423-455.

Piper, C. J., McLachlin, R. D., 1990. Just-in-time Production: Eleven achievable dimensions. Operations Management Review, 7 (3-4), 1-8.

Powell, T. C., 1995. Total quality management as competitive advantage: A review and empirical study. Strategic Management Journal, 16(1), 15-27.

Roth, A. V., van der Velde, M., 1991. Operations as Marketing: A competitive Service Strategy. Journal of Operations Management, 10 (3), 303-328.

Sakakibara, S., Flynn, B. B., Schroeder, R. G., Morris, W. T., 1997. The impact of justin-time manufacturing and its infrastructure on manufacturing performance. Management Science, 43 (9), 1246-1257.

Samson, D., Terziovski, M., 1999. The Relationship between Total Quality Management Practices and Operational Performance. Journal of Operations Management, 17 (5), 393409.

Schonberger, R. J., 1982. Japanese Manufacturing Techniques: Nine hidden lessons in simplicity. The Free Press, New York.

Schonberger, R. J., 1986. World Class Manufacturing: The Lessons of Simplicity Applied. The Free Press, New York.

Schroeder, R. G., Flynn, B. B., 2001. High Performance Manufacturing: Global perspectives. John Wiley, New York. 
Shingo Prize Guidelines, 1996. Richey, D., The Shingo Prize for excellence in manufacturing. Journal for Quality and Participation, 19 (4), 28-31.

Skinner, W., 1969. Manufacturing - missing link in corporate strategy. Harvard Business Review, 50 (1), 136-145.

Smith, T. W., 1994. A comparison or two confidence intervals. GSS Methodological Report No. 80, National Opinion Research Center, Chicago, IL.

Smith, T. W., Peterson, B. L., 1985. The impact of number of response categories on inter-item associations: Experimental and simulated studies. Presented at American Sociological Association Meetings, Washington, D.C.

Stinchcombe, A., 1965. Social structure and organizations. In: March, J. (Eds.), Handbook of industrial organization, Rand McNally, Chicago, IL, pp. 142-193.

Stock, G. N., Greis, N. P., Kasarda, J. D., 2000. Enterprise logistics and supply chain structure. Journal of Operations Management, 18 (5), 531-547.

Sugimori, Y., Kusunoki, F., Cho, F., Uchikawa, S., 1977. Toyota production system and kanban system: Materialization of just-in-time and respect for human systems.

International Journal of

Production Research, 15 (6), 553-564.

Suzaki, K., 1985. Japanese Manufacturing Techniques: their importance to US manufacturers. Journal of Business Strategy, 5 (3), 10-19.

Tushman, M. L., Anderson, P., 1986. Technological discontinuities and organizational environments. Administrative Science Quarterly, 31 (3), 439-465.

U. S. Census of Manufacturers, 1997, http://www.census.gov/

Vickery, S. K., 1991. A Theory of Production Competence Revisited. Decision Sciences, 22 (3), 635-643.

Voss, C. A., Robinson, S. J., 1987. Application of just-in-time manufacturing techniques in the United Kingdom. International Journal of Operations and Production Management, 7 (4), 46-52.

Wantuck, K. A., 1983. The Japanese approach to productivity, In: Chase, R., Aquilano (Eds.). Production and Operations Management: A life cycle approach. $6^{\text {th }}$ ed. Irwin, Homewood, IL.

White, R. E., 1993. An empirical assessment of JIT in US manufacturers. Production and Inventory Management Journal, 34 (2), 38-42. 
White, R. E., Pearson, J. N., Wilson, J. R., 1999. JIT Manufacturing: A survey of implementation in small and large US manufacturers. Management Science, 45 (1), 1-15.

Womack, J. P., Jones, D. T., 1996. Lean Thinking: Banish waste and create wealth in your corporation. Simon \& Schuster, New York.

Womack, J. P., Jones, D. T., Roos, D., 1990. The machine that changed the world. Harper Perennial: New York. 
Table 1

Lean practices and their appearance in key references (adapted from McLachlin, 1997)

Sources

Bottleneck removal (production smoothing) Cellular manufacturing

Competitive Benchmarking Continuous improvement programs

Cross functional work force Cycle time reductions

Focused factory production JIT/ continuous flow production

Lot size reductions

Maintenance optimization

New process

equipment/technologies

Planning and scheduling strategies

Preventive maintenance

Process capability

measurements

Pull System/Kanban

Quality Management Programs

Quick changeover techniques

Reengineered production process

Safety improvement programs

Self directed work teams

Total quality management
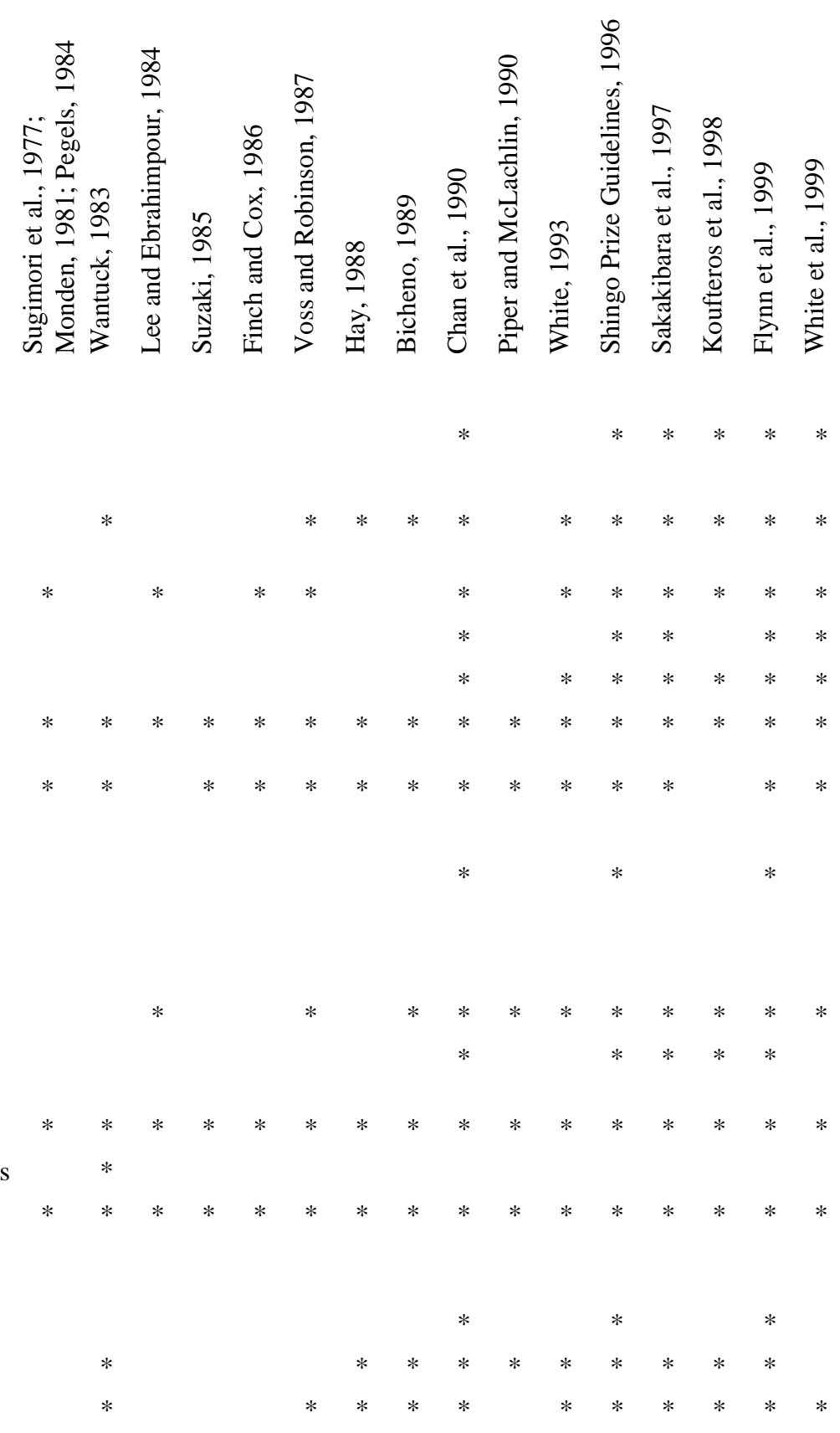
Table 2

Comparison of the study sample with US Census of Manufacturers (1997) by SIC code

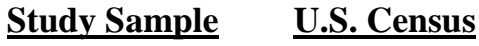

Standard Industrial Classification

Num
(1997)

20 Food and Products

21 Tobacco Products

22 Textile Mill Products

23 Apparel and other textile

24 Lumber and Wood

25 Furniture and Fixtures

26 Paper

27 Printing and Publishing

28 Chemicals

29 Petroleum and Coal

30 Rubber and Misc. Plastic

31 Leather

$\frac{(1997)}{\%}$

5.5

$\begin{array}{lll}3 & 0.2 & 0.04\end{array}$

$\begin{array}{lll}41 & 2.3 & 1.6\end{array}$

$\begin{array}{lll}22 & 1.3 & 6.2\end{array}$

$\begin{array}{lll}39 & 2.2 & 9.7\end{array}$

$\begin{array}{lll}58 & 3.3 & 3.2\end{array}$

$\begin{array}{lll}86 & 4.9 & 1.7\end{array}$

$27 \quad 1.5 \quad 16.4$

$\begin{array}{lll}130 & 7.4 & 3.3\end{array}$

$\begin{array}{lll}10 & 0.6 & 0.6\end{array}$

$\begin{array}{lll}107 & 6.1 & 4.4\end{array}$

32 Stone, Clay, and Glass

$\begin{array}{lll}6 & 0.3 & 0.5\end{array}$

33 Primary Metal

$53 \quad 3.0$

4.3

$90 \quad 5.1 \quad 1.7$

34 Fabricated Metal

$202 \quad 11.5$

10.1

35 Machinery, except elect.

$307 \quad 17.5$

14.9

36 Electric and electronic equip.

$219 \quad 12.5$

4.5

37 Transportation Equip.

$141 \quad 8.1$

3.3

38 Instruments and Related Products

112

29

6.4

3.1

39 Misc. Manufacturing

TOTAL

$1,748 \quad 100 \% \quad 100 \%$


Table 3

Spearman's correlations between union, age, size and manufacturing practices ${ }^{\mathrm{a}}$

\begin{tabular}{|c|c|c|c|c|c|c|c|c|c|c|c|c|c|c|c|c|c|c|c|c|c|c|c|c|c|}
\hline & 1 & 2 & 3 & 4 & 5 & 6 & 7 & 8 & 9 & 10 & 11 & 12 & 13 & 14 & 15 & 16 & 17 & 18 & 19 & 20 & 21 & 22 & 23 & 24 & 25 \\
\hline 1 & - & .00 & .00 & & & .03 & .00 & .01 & .07 & .02 & & & & & & & .00 & & .04 & .01 & & & .01 & & \\
\hline 2 & .11 & - & .06 & .00 & .00 & .00 & & .00 & .00 & .00 & .00 & .00 & .09 & .00 & .00 & .00 & .00 & .00 & .00 & .00 & .00 & .00 & .01 & .00 & .00 \\
\hline 3 & .24 & .05 & - & & & .01 & .00 & & & .08 & .03 & & & & & .00 & .07 & & & & & & .02 & & \\
\hline 4 & .01 & .16 & -.01 & - & .00 & .00 & .00 & .00 & .00 & .00 & .00 & .00 & .00 & .00 & .00 & .00 & .00 & .00 & .00 & .00 & .00 & .00 & .00 & .00 & .00 \\
\hline 5 & .01 & .08 & -.03 & .28 & - & .00 & .00 & .00 & .00 & .00 & .00 & .00 & .00 & .00 & .00 & .00 & .00 & .00 & .00 & .00 & .00 & .00 & .00 & .00 & .00 \\
\hline 6 & -.05 & .10 & $\begin{array}{l}.06 \\
\end{array}$ & .31 & .16 & - & .00 & .00 & .00 & .00 & .00 & .00 & .00 & .00 & .00 & .00 & .00 & .00 & .00 & .00 & .00 & .00 & .00 & .00 & .00 \\
\hline 7 & -.14 & -.02 & -.08 & .21 & .18 & .34 & - & .00 & .00 & .00 & .00 & .00 & .00 & .00 & .00 & .00 & .00 & .00 & .00 & .00 & .00 & .00 & .00 & .00 & .00 \\
\hline 8 & -.07 & .11 & -.04 & .25 & .30 & .15 & .23 & - & .00 & .00 & .00 & .00 & .00 & .00 & .00 & .00 & .00 & .00 & .00 & .00 & .00 & .00 & .00 & .00 & .00 \\
\hline 9 & .04 & .10 & -.01 & .28 & .22 & .22 & .18 & .19 & - & .00 & .00 & .00 & .00 & .00 & .00 & .00 & & .00 & .00 & .00 & .00 & .00 & .00 & .00 & .00 \\
\hline 10 & $\begin{array}{l}-.06 \\
\end{array}$ & .16 & $\begin{array}{l}.04 \\
\end{array}$ & .17 & .24 & .13 & .13 & .18 & .22 & - & .00 & .00 & .00 & .00 & .00 & .00 & .00 & .00 & .00 & .00 & .00 & .00 & .00 & .00 & .00 \\
\hline 11 & .01 & .09 & .05 & .22 & .20 & .17 & .18 & .26 & .27 & .17 & 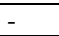 & .00 & .00 & .00 & .00 & .00 & .00 & .00 & .00 & .00 & .00 & .00 & .00 & .00 & .00 \\
\hline 12 & .02 & .09 & -.01 & .27 & .30 & .21 & .28 & .34 & .23 & .21 & .38 & - & .00 & .00 & .00 & .00 & .00 & .00 & .00 & .00 & .00 & .00 & .00 & .00 & .00 \\
\hline 13 & .01 & .04 & -.01 & .41 & .17 & .18 & .16 & .16 & .22 & .18 & .23 & .21 & - & .00 & .00 & .00 & .00 & .00 & .00 & .00 & .00 & .00 & .00 & .00 & .00 \\
\hline 14 & -.02 & .10 & -.01 & .23 & .25 & .14 & .18 & .32 & .20 & .24 & .22 & .36 & .10 & - & .00 & .00 & .00 & .00 & .00 & .00 & .00 & .00 & .00 & .00 & .00 \\
\hline 15 & $\begin{array}{l}-.02 \\
\end{array}$ & .15 & $\begin{array}{l}.04 \\
\end{array}$ & .22 & .25 & .23 & .19 & .25 & .15 & .17 & .18 & .33 & .14 & .33 & - & .00 & .00 & .00 & .00 & .00 & .00 & .00 & .00 & .00 & .00 \\
\hline 16 & .01 & .14 & -.07 & .28 & .28 & .22 & .23 & .36 & .19 & .18 & .24 & .33 & .16 & .34 & .41 & - & .00 & .00 & .00 & .00 & .00 & .00 & .00 & .00 & .00 \\
\hline 17 & -.07 & .11 & -.05 & .12 & .22 & .17 & .16 & .25 & .01 & .12 & .12 & .21 & .09 & .23 & .31 & .33 & - & .00 & .00 & .00 & .00 & .00 & & .00 & .00 \\
\hline 18 & .01 & .09 & -.03 & .44 & .25 & .26 & .22 & .22 & .29 & .19 & .23 & .28 & .51 & .22 & .27 & .31 & .20 & - & .00 & .00 & .00 & .00 & .00 & .00 & .00 \\
\hline 19 & .05 & .21 & -.02 & .34 & .16 & .17 & .14 & .17 & .23 & .19 & .13 & .19 & .32 & .22 & .20 & .26 & .20 & .37 & - & & & & .00 & .00 & .00 \\
\hline 20 & .07 & .20 & .00 & .31 & .25 & .24 & .19 & .23 & .27 & .21 & .25 & .29 & .24 & .24 & .21 & .28 & .12 & .33 & .32 & - & & & .00 & .00 & .00 \\
\hline 21 & -.03 & .11 & .03 & .16 & .21 & .13 & .18 & .33 & .07 & .11 & .25 & .31 & .10 & .27 & .27 & .35 & .36 & .16 & .14 & .21 & - & & .00 & .00 & .00 \\
\hline 22 & .03 & .09 & -.03 & .30 & .18 & .16 & .17 & .15 & .55 & .21 & .23 & .19 & .24 & .20 & .10 & .17 & -.01 & .30 & .22 & .27 & .10 & - & .00 & .00 & .00 \\
\hline 23 & .06 & .07 & .06 & .27 & .14 & .17 & .15 & .11 & .26 & .19 & .24 & .16 & .23 & .16 & .13 & .14 & $\begin{array}{l}-.03 \\
\end{array}$ & .28 & .15 & .24 & .10 & .37 & - & .00 & .00 \\
\hline 24 & -.00 & .16 & -.03 & .25 & .23 & .17 & .19 & .30 & .09 & .11 & .19 & .27 & .16 & .21 & .31 & .46 & .41 & .24 & .25 & .21 & .39 & .08 & .06 & - & .00 \\
\hline 25 & -.00 & .11 & -.01 & .28 & .27 & .21 & .26 & .35 & .24 & .21 & .31 & .35 & .17 & .31 & .28 & .37 & .23 & .28 & .24 & .30 & .29 & .26 & .26 & .35 & - \\
\hline
\end{tabular}

1=Union, 2=Size, 3=Age, 4=Continuous improvement Programs, 5=Reengineered Production Process, 6=Self directed Work Teams, 7=Cross Functional work force, 8=Cycle Time Reduction, 9=Maintenance Optimization, 10=New Process equipment or Technologies, 11=Planning and Scheduling Strategies, 12=Agile Manufacturing Strategies,

13=Quality Management Programs, 14=Quick Changeover Techniques, 15=Focused Factory Production Systems, 16=JIT/continuous Flow Production, 17=Cellular

Manufacturing, 18=TQM , 19=Process Capability Measurements, 20=Competitive Benchmarking, 21=Lot Size Reductions, 22=Preventive Maintenance, 23=Safety Improvement

Programs, 24=Pull System/Kanban, 25=Bottleneck Removal

${ }^{a}$ Values below diagonal are Spearman’s correlations and values above diagonal are p-values. Only significant p-values are shown. 
Table 4:

Exploratory Factor Analysis to validate lean bundles -- Rotated Component Matrix

\begin{tabular}{|c|c|c|c|c|}
\hline & \multicolumn{4}{|c|}{ Factor Loadings } \\
\hline & JIT & TPM & TQM & HRM \\
\hline Lot-size reductions & .659 & .062 & .007 & .031 \\
\hline JIT/continuous-flow production & .649 & .081 & .213 & .116 \\
\hline Pull system & .647 & -.147 & .256 & .118 \\
\hline Cellular manufacturing & .631 & -.234 & .180 & .105 \\
\hline Cycle-time reductions & .586 & .248 & .014 & .054 \\
\hline Focused-factory production systems & .562 & .051 & .170 & .164 \\
\hline Agile manufacturing strategies & .552 & .327 & .075 & .146 \\
\hline Quick changeover techniques & .537 & .336 & .030 & -.064 \\
\hline Bottleneck/constraint removal & .501 & .349 & .126 & .151 \\
\hline Reengineered production processes & .440 & .288 & .138 & .023 \\
\hline Predictive or preventive maintenance & -.001 & .715 & .198 & .116 \\
\hline Maintenance optimization & .038 & .681 & .168 & .176 \\
\hline Safety improvement programs & .012 & .552 & .240 & .089 \\
\hline Planning and scheduling strategies & .314 & .458 & .050 & .141 \\
\hline New process equipment or technologies & .248 & .418 & .147 & -.197 \\
\hline Competitive benchmarking & .256 & .364 & .361 & .073 \\
\hline Quality management programs & .024 & .178 & .741 & .079 \\
\hline Total Quality Management & .177 & .219 & .705 & .160 \\
\hline Process capability measurements & .211 & .101 & .660 & -.079 \\
\hline $\begin{array}{l}\text { Formal continuous improvement } \\
\text { program }\end{array}$ & .179 & .271 & .605 & .206 \\
\hline Self-directed work teams & .138 & .128 & .208 & .758 \\
\hline Flexible, cross-functional workforce & .259 & .177 & .042 & .710 \\
\hline Eigenvalue & 5.88 & 1.98 & 1.25 & 1.05 \\
\hline Initial Percent of Variance Explained & 26.74 & 9.01 & 5.67 & 4.72 \\
\hline $\begin{array}{l}\text { Rotation Sum of Squared Loadings } \\
\text { (Total) }\end{array}$ & 3.79 & 2.58 & 2.39 & 1.39 \\
\hline Percent of Variance Explained & 17.23 & 11.74 & 10.85 & 6.33 \\
\hline Cronbach Alpha (sample N) & $.81(1508)$ & $.74(1579)$ & $.74(1588)$ & $.51(1709)$ \\
\hline
\end{tabular}

Extraction Method: Principal Component Analysis. Rotation Method: Varimax with Kaiser Normalization. 
Table 5

Operational Performance: Factor loading, means, standard deviation and Spearman correlation.

\begin{tabular}{|c|c|c|c|c|c|c|c|c|}
\hline 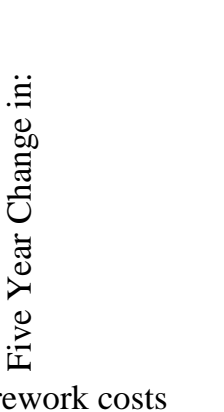 & 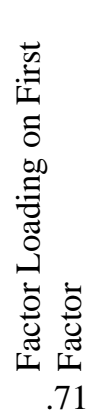 & $\begin{array}{l}\sum_{3.77}^{\text {ङू }} \\
3.77\end{array}$ & 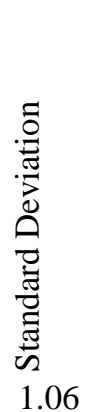 & 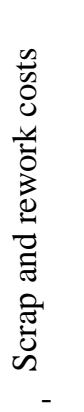 & 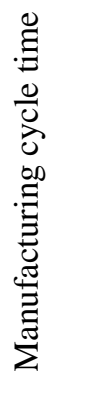 & 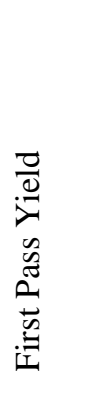 & 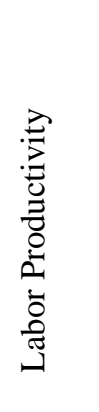 & 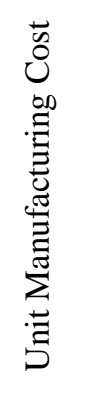 \\
\hline cycle time & .70 & 2.65 & 1.25 & 0.32 & - & & & \\
\hline & .61 & 4.10 & 0.93 & 0.50 & 0.28 & - & & \\
\hline ivity & .61 & 4.67 & 1.42 & 0.27 & 0.33 & 0.23 & - & \\
\hline aring Cost & .58 & 4.52 & 1.46 & 0.31 & 0.30 & 0.17 & 0.35 & - \\
\hline l-time & .53 & 4.05 & 1.11 & 0.22 & 0.40 & 0.18 & 0.18 & 0.19 \\
\hline
\end{tabular}

Eigenvalue (Variance Explained) $\quad 2.36$ (39.26\%)

Cronbach Alpha $\quad 0.69$

*Pairwise deletion method used, sample size differs for each bi-variate pair. All correlations are significant at 0.01 level (2-tailed). 
Table 6

Pearson's chi-square to test for association between contextual variables and implementation of lean practices. ${ }^{\text {a }}$

$\begin{array}{lccc} & \text { Unionization } & \text { Age } & \text { Size } \\ & & & \\ \text { Agile Manufacturing Strategies } & 2.85 & .92 & 14.30^{* *} \\ \text { Bottleneck Removal } & .01 & 1.39 & 20.73^{* * *} \\ \text { Cellular Manufacturing } & (17.89)^{* * *} & 8.18 & 23.86^{* * *} \\ \text { Competitive Benchmarking } & 7.62 & 1.32 & 70.32^{* * *} \\ \text { Continuous Improvement Programs } & 6.24 & 8.54 & 44.32^{* * *} \\ \text { Cross Functional work force } & (39.99)^{* * *} & (18.07)^{* * *} & .50 \\ \text { Cycle Time Reduction } & (10.68)^{*} & 7.23 & 21.86^{* * *} \\ \text { Focused Factory Production Systems } & .85 & 8.35 & 40.10^{* * *} \\ \text { JIT/continuous Flow Production } & 1.37 & (12.69)^{*} & 35.44^{* * *} \\ \text { Lot Size Reductions } & 2.72 & 2.58 & 18.96^{* * *} \\ \text { Maintenance Optimization } & (13.75)^{* *} & (10.75)^{*} & 22.35^{* * *} \\ \text { New Process equipment or Technologies } & 7.24 & 4.35 & 48.73^{* * *} \\ \text { Planning and Scheduling Strategies } & 5.13 & 13.03 * * & 13.04^{* *} \\ \text { Preventive Maintenance } & 3.24 & 6.72 & 33.19^{* * *} \\ \text { Process Capability Measurements } & (11.06)^{* *} & 6.44 & 75.06^{* * *} \\ \text { Pull System/Kanban } & 4.78 & 7.70 & 42.52^{* * *} \\ \text { Quality Management Programs } & 1.56 & 6.04 & 6.75 \\ \text { Quick Changeover Techniques } & 2.53 & 5.07 & 22.54^{* * *} \\ \text { Reengineered Production Process } & .88 & (10.72)^{* *} & 16.34^{* *} \\ \text { Safety Improvement Programs } & 8.61 & 13.92^{* *} & 25.90^{* * *} \\ \text { Self directed Work Teams } & (18.50)^{* * *} & (15.87)^{* *} & 20.74^{* * *} \\ \text { Total Quality Management } & 6.50 & 12.00^{*} & 13.72^{* *} \\ & & & \\ \text { *p }<.05 ; * * p<.01 ; * * * p<.001 & & & \\ \text { a All significant associations are positive except for those in parentheses, which indicate negative } \\ \text { association. } & & & \end{array}$


Table 7

Results from Hierarchical Regression Analysis - dependent variable is factor score for operational performance

\begin{tabular}{|c|c|c|c|}
\hline & & rdized Beta & cients \\
\hline & Model 1 & Model 2 & Model 3 \\
\hline Dummy 20 & -.120 & $-.123 *$ & -.065 \\
\hline Dummy 22 & -.009 & -.013 & .009 \\
\hline Dummy 23 & -.029 & -.035 & -.023 \\
\hline Dummy 24 & $-.116 * *$ & $-.120^{* *}$ & -.070 \\
\hline Dummy 25 & -.045 & -.046 & -.034 \\
\hline Dummy 26 & -.065 & -.068 & -.026 \\
\hline Dummy 27 & -.024 & -.025 & .014 \\
\hline Dummy 28 & -.070 & -.074 & -.029 \\
\hline Dummy 29 & -.037 & -.039 & -.023 \\
\hline Dummy 30 & -.049 & -.051 & -.027 \\
\hline Dummy 31 & $-.068 *$ & $-.071^{*}$ & -.035 \\
\hline Dummy 32 & -.056 & -.055 & -.014 \\
\hline Dummy 33 & -.010 & -.017 & .026 \\
\hline Dummy $34^{\mathrm{a}}$ & -.007 & -.003 & -.013 \\
\hline Dummy $35^{\mathrm{a}}$ & -.091 & -.096 & -.058 \\
\hline Dummy $36^{\mathrm{a}}$ & .023 & .015 & .017 \\
\hline Dummy $37^{\mathrm{a}}$ & -.028 & -.046 & -.097 \\
\hline Dummy 38 & .003 & -.003 & .023 \\
\hline Union & & .017 & .027 \\
\hline Size & & .026 & $-.068 *$ \\
\hline Age & & $-.079 * *$ & $-.072 * *$ \\
\hline JIT & & & $.431^{* * *}$ \\
\hline TPM & & & $.176 * * *$ \\
\hline TQM & & & $.190 * *$ \\
\hline HRM & & & $.097^{* *}$ \\
\hline $\mathrm{R}^{2}$ & .040 & .046 & .277 \\
\hline Adjusted $\mathrm{R}^{2}$ & .024 & .028 & .261 \\
\hline Change in $\mathrm{R}^{2}$ & .040 & .006 & .231 \\
\hline p-value of F Statistic & .001 & .051 & .000 \\
\hline p-value of overall model & .001 & .001 & .000 \\
\hline
\end{tabular}

${ }^{*} p<.05 ; * * p<.01 ; * * * p<.000$

${ }^{a}$ The Variance Inflation Factor is greater than five for each of these variables in each of the models indicating multicollinearity. 
Table 8

Industry Effects: Analysis of variance comparing mean values of implementation of each of the lean bundles by industry category (process or discrete part) ${ }^{\mathrm{a}}$

$\underline{\text { Mean }}^{\mathrm{b}}$

$\begin{array}{llll}\text { JIT } & \text { TPM } & \text { TQM } & \text { HRM }\end{array}$

$\begin{array}{lrrrr}\text { Process }(\mathrm{n}=251) & -.596 & .546 & .032 & -.029 \\ \text { Discrete }(\mathrm{n}=829) & .268 & -.214 & -.001 & .034 \\ \text { Total }(\mathrm{n}=1080) & .067 & -.037 & .003 & .020\end{array}$

ANOVA

Sum of Squares

Between Groups

$\begin{array}{lrrr}143.84 & 111.35 & .28 & .77\end{array}$

Within Groups

970.89

945.84

$1,038.61 \quad 1,076.50$

Total

$1,114.73$

$1,057.19 \quad 1,038.89$

$1,077.27$

df

Between Groups

1
1,078
1,079

1

1

Within Groups

1,078

1,078

1

Total

1,079

1,078

143.8

Mean Square

Between Groups
Within Groups

143.84

111.35

1,079

1,079

0.90

.88

.28

.77

159.71

126.91

.29

.77

Sig.

.000

.000

.591

.381

a. Process industries include SICs 20 Food Products, 22 Textile Mill Products, 26 Paper, and 28 Chemicals. Discrete part industries include SICs 34 Fabricated Metals, 35 Machinery, 36 Electronics, 37 Transportation Equipment, and 38 Instruments.

b. Standardized mean values of each of the lean bundles (JIT, TPM, TQM, HRM). 